\title{
WACANA FIKSIMINI BAHASA INDONESIA: ANALISIS STRUKTUR, KETERPADUAN, PERMAINAN BAHASA, DAN FUNGSI
}

\author{
Cicik Tri Jayanti
}

Universitas Trunojoyo Madura

\begin{abstract}
This study is aimed to describe the characteristics of mini fiction by explaining the structure and coherence between elements, forms of language, and discourse functions in Indonesian mini fiction. It is a qualitative study by using mini fiction discouse as research objects. The research data were in the form of tweets by the users who retweeted any tweets from @fiksimini account. Thus, the data collected in the research were written and collected by transcribing the data. The results of the study showed that (1) the structure of mini fiction discourse consists of three elements, topic, title and content; (2) the language play in the discourse was presented through the reader's understanding of the texts and some distortion of the language varieties; and (3) the mini fiction discourse has four functions, such as emotive, retorical, cognitive and poetic speech function.
\end{abstract}

Keywords: mini fiction discourse, structure, language play, language function.

\begin{abstract}
Abstrak: Penelitian ini bertujuan untuk mendeskripsikan karakteristik wacana fiksimini yang dalam bahasa Indonesia merupakan ragam wacana baru. Penelitian ini merupakan penelitian kualitatif dengan menggunakan wacana fiksimini sebagai objek penelitian. Data penelitian ini berupa tweetfiksimini dari para fiksiminier yang di-retweet dalam akun @fiksimini. Sumber data yang digunakan dalam penelitian ini ialah sumber data tertulis. Pengambilan data dilakukan dengan menggunakan teknik catat. Adapun hasil penelitian memuat tiga penjelasan. Pertama, struktur wacana fiksimini terdiri atas tiga unsur, yakni topik, judul, dan isi. Kedua, Permainan bahasa dalam wacana fiksimini pada umumnya disajikan dengan menghadirkan pemahaman umum pembacanya, kemudian disimpangkan menggunakan beberapa varian aspek kebahasaan. Ketiga, terdapat empat fungsi fiksimini yang ditemukan, yakni emotif, retorikal, kognitif, dan poetic speech.
\end{abstract}

Kata Kunci: wacana fiksimini, struktur dan keterpaduan, permainan bahasa, fungsi bahasa

Wacana dapat dipilah berdasarkan beberapa kriteria, salah satunya ialah tujuan komunikasi. Rani, Arifin, dan Martutik (2004:37) menyatakan bahwa berdasarkan tujuan komunikasi, 
wacana dapat dibedakan menjadi wacana deskripsi, eksposisi, argumentasi, persuasi, dan narasi. Oka dan Suparno (1994:271) berpendapat bahwa wacana naratif lazim digunakan untuk mengungkapkan hal-hal yang sudah mengalami proses pengimajian. Wujud naratif yang konkret berupa karya sastra, seperti cerpen, novel, dan roman. Dalam wacana itu terungkap bukan hanya pengalaman yang konkret, tetapi pengalaman imajinatif.

Uniknya, ditemukan penyesuaian panjang pendeknya wacana naratif yang sejalan dengan perkembangan medianya. Wacana naratif panjang dapat dijumpai dengan mudah di toko buku, berupa novel, kumpulan cerpen, maupun cerpen dalam media cetak. Sementara itu, terdapat pula wacana naratif pendek yang berkembang di media-media sosial. Hadirnya wacana naratif pendek dapat dimaklumi melalui penjelasan Faruk (2011: 27-28) yang menyatakan bahwa sensibilitas multimedia telah melahirkan kecenderungan baru dalam hasil-hasil karya sastra, yaitu kecenderungan pascamodern. Sebagai produk dari sensibilitas tersebut, karya sastra bukan lagi merupakan sebuah teks yang tertutup, yang lengkap dengan dirinya, melainkan sebuah teks yang terbuka dan yang membuka diri, yang koekstensif dengan segala sesuatu yang ada di luar dirinya. Baik yang berupa citra-citra indrawi yang berbeda, dengan teks-teks lain, genre-genre lain, wacana-wacana lain, maupun dengan dunia nyata yang historis. Pendek kata, secara ontologis, karya-karya sastra pascamodern adalah karya yang menghadirkan dirinya sedemikian rupa sebagai dan sekaligus berada dalam sebuah proses diskursif yang terbuka dan historis, bukan sesuatu yang final. Lantas, Budiwati (2011) juga menambahkan istilah historis sebagai aspek yang kuat untuk memulai meneliti sebuah teks.

Sebab akibat seperti paparan itulah yang kurang lebih dialami oleh wacana fiksimini. Kartikasari dkk (2014:50) mendefinisikan fiksimini sebagai karya sastra seratus empat puluh karakter yang berkembang di media sosial. Angka seratus empat puluh merupakan jumlah yang diperoleh dari karakter maksimal penulisan dalam twitter. Oleh karenanya, twitter menjadi lahan pertumbuhan fiksimini bagi para fiksiminier — sebutan untuk penulis fiksimini-dan para penikmatnya.

Dalam realisasinya, fiksimini di Indonesia terus tumbuh dan berkembang atas prakarsa fiksiminier senior, yakni Clara Ng, Agus Noor, dan Salman Aristo. Pada tahapan selanjutnya, ketiganya menjadi tokoh berpengaruh di balik lahirnya komunitas akun twitter @ fiksimini yang menjadi wadah perkumpulan para pecinta fiksimini. Hingga akhir tahun 2014, akun tersebut memiliki 164.505 pengikut.

Sedikitnya, terdapat empat tahapan dalam terciptanya wacana fiksimini. Berikut merupakan empat kronologi terciptanya fiksimini dalam satuan waktu: (1) Para anggota mengusulkan topik pada akun @fiksimini; (2) Topik yang diajukan diterima apabila moderator me-retweet usulan tersebut dengan menambahkan hashtag \#topikfiksimini atau apabila tak ada salah satu pun usulan yang diterima, moderator mengajukan topik tertentu dengan pola hashtag yang sama; (3) Selanjutnya, para anggota menulis fiksimini sesuai topik hari itu kemudian admin-disebut juga dengan istilah moderator-mulai memilih tulisan yang paling bagus dan sesuai topik dengan me-retweet fiksimini tesebut; (4) Fiksminini yang muncul pada halaman akun @fiksimini hanyalah fiksimini yang berhasil di-retweet oleh moderator setelah melalui serangkaian pertimbangan.

Mengingat terbatasnya jumlah karakter maksimal dalam penulisan fiksimini, setiap satuan gramatikal dipilah dan dipilih agar mendukung topik yang telah disepakati sebelumnya. Mengenai hal tersebut, Keraf (1985:22 - 23) menyatakan bahwa pilihan kata tidak hanya dipergunakan untuk menyatakan kata-kata mana yang dipakai untuk mengungkapkan suatu ide atau gagasan, tetapi juga meliputi persoalan fraseologi, gaya 
bahasa, dan ungkapan. Untuk itulah, fiksimini memiliki tiga istilah utama yang harus dipahami fiksiminier sebelum menulis fiksimini, yakni (1) topik, (2) judul, dan (3) isi fiksimini. Penjelasan mengenai ketiga istilah tersebut dapat dilihat melalui percontohan berikut.

(581) Yuk mainkan imajinasimu! Semua seputar WISATA DOMESTIK. Alam, budaya, dan kuliner. \#topikfiksimini.

(589) SENJA DI KARIMUN JAWA. Perlahan aku tenggelam digantikan malam, sepasang kekasih melihatku riang dari kejauhan.

(583) BAKSO MALANG-"Ibu, coba lihat ini, ada orang menangis dalam mangkukku."

LAWANG SEWU. Toiletnya malah 2000.

LONTONG BALAP SURABAYA - Kami menikmatinya dengan kecepatan penuh.

Data (581) merupakan contoh topik. Topik yang digunakan ialah kata yang dicetak kapital, yakni wisata domestik. Selanjutnya, data (589), (583), (590), dan (594) merupakan contoh fiksimini edisi topik wisata domestik. Kata bercetak kapital pada data (589), (583), (590), dan (594) merupakan judul fiksimini, yakni Senja di Karimun Jawa, Bakso Malang, Lawang Sewu, dan Lontong Balap Surabaya. Sementara itu, satuan kebahasaan setelahnya merupakan isi dari fiksimini.

Melalui kelima data tersebut, dapat dilihat bahwa fiksimini memiliki sejumlah keunikan. Bentuknya yang mini menghasilkan struktur wacana tak biasa. Menariknya, antara judul satu dengan judul lainnya sekilas tak berhubungan, tetapi disatukan oleh topik yang sama, yakni wisata domestik.

Wacana fiksimini juga mengandung permainan bahasa yang variatif dan kreatif. Pada data (589) 'aku' yang bercerita merupakan personifikasi dari matahari. Kemudian, data (583) dan (594) sepakat memplesetkan relasi makna judulnya. Seharusnya, bakso malang merupakan nama bakso khas dari Malang. Begitu pula dengan lontong balap Surabaya. Akan tetapi, relasi makna bakso malang dengan lontong balap Surabaya diganti menjadi bakso yang malang dan lontong yang harus dinikmati dengan balapan.

Hal berbeda ditunjukkan pada data (590) yang seolah-olah mengontraskan jumlah pintu di lawang sewu dengan jumlah pintu toiletnya. Padahal, maksud dari penulisnya ialah mempermainkan logika jumlah pintu dengan harga toilet di objek wisata itu. Tentu saja dengan didahului proses memaknai nama objek wisata 'lawang sewu' dengan 'pintu yang jumlahnya seribu'.

Permainan logika jumlah pintu pada data (590) tersebut ternyata bukan tanpa makna. Fiksimini tersebut dapat pula dimaknai sebagai satu dari sekian media untuk menyampaikan kritik sosial terhadap ketimpangan antara besaran harga dengan fasilitas yang diterima pelanggan toilet di objek-objek wisata. Sejalan dengan hal tersebut, Wijana dan Rohmadi (2011:99) menyatakan bahwa kritikan-kritikan atau serangan-serangan yang disampaikan dengan ungkapan-ungkapan kolektif atau formula-formula berkias bersifat impersona sehingga ketajamannya tidak dirasakan sebagai serangan langsung oleh sasarannya. Contoh mengenai fungsi bahasa sebagai wahana kritik sosial dapat pula dilihat melalui wacana fiksimini bertopik Di Bawah Langit Jakarta pada data (152) sampai dengan (163) sebagai berikut. 
Topik: Di Bawah Langit Jakarta

Apa yang kau lihat DI BAWAH LANGIT JAKARTA, fiksiminier? Ada 2 novel untukmu! \#topikfiksimini (1 Agustus 2014)

(152) DI BAWAH LANGIT JKT "Bapakku org terkaya. Atap rumah kami saja 5 miliar!" ujar anak itu di bawah kolong jembatan. (2 Agustus 2014).

DI BAWAH LANGIT JAKARTA-“Berteduhlah pada doa...” (1 Agustus 2014).

Sejumlah data di atas berisi tentang kritikan fiksiminier terhadap Jakarta. Dari data (152) berisi kritikan terhadap ketimpangan antara kaum bawah dan kaum atas. Data (162) misalnya, menggambarkan kejamnya Jakarta sehingga mereka yang di sana tak dapat berteduh di mana dan pada siapa pun kecuali pada Tuhan melalui doa.

Selain sebagai salah satu alat menyampaikan kritik terhadap keadaan sekitar, fiksimini juga memiliki fungsi bahasa lainnya mengingat wacana jenis ini mengandung sejumlah permainan bahasa. Wijana dan Rohmadi (2012:59) menyatakan bahwa pada umumnya dan mulanya, eksploitasi bahasa digunakan untuk bersenda gurau, melucu atau mengejek, serta menertawakan sesuatu yang dianggap lucu atau ironis. Akan tetapi, tidak dipungkiri pula muncul dalam modus tuturan yang lebih serius, namun nuansa jenakanya masih bisa ditangkap.

Berdasarkan uraian di atas, wacana fiksimini memiliki struktur dan keterpaduan, permainan bahasa, serta fungsi bahasa yang khas dibandingkan dengan genre naratif lainnya. Dengan demikian, peneliti tertarik untuk meneliti wacana fiksimini bahasa Indonesia yang ditinjau dari tiga aspek, yakni (1) struktur dan keterpaduan, (2) permainan bahasa, serta (3) fungsi bahasa yang terdapat di dalamnya.

\section{METODE}

Penelitian ini merupakan penelitian kualitatif dengan menggunakan wacana fiksimini sebagai objek penelitian. Data penelitian ini berupa tweetfiksimini dari para fiksiminier yang di-retweet dalam akun @fiksimini. Sumber data yang digunakan dalam penelitian ini ialah sumber data tertulis. Sumber data tertulis yang dimaksud berupa twitter dari akun @ fiksimini.

Pengambilan data dilakukan dengan menggunakan teknik catat. Selanjutnya, pembatasan data penelitian dilakukan dengan mengambil data melalui akun twitter @ fiksimini mulai 4 Juni hingga 3 November 2014. Selain itu, data yang diambil hanya untuk keperluan menjawab tiga rumusan masalah yang diajukan semata.

Setelah data berhasil terhimpun, dilakukan analisis terhadap tiga plot. Pertama, struktur wacana fiksimini dan hubungan keterpaduan antarunsur dalam wacana fiksimini. Kedua, karakteristik permainan bahasa dalam wacana fiksimini. Ketiga, fungsi bahasa wacana

fiksimini bahasa Indonesia. Ketiga tindakan tersebut dilakukan secara bertahap dan berurutan.

Sudaryanto (1993:6) menyatakan bahwa analisis dimulai tepat pada saat penyediaan data tertentu yang relevan selesai dilakukan; dan analisis yang sama diakhiri atau boleh dipandang berakhir mana kala kaidah yang berkenaan dengan objek yang yang menjadi masalah itu telah ditemukan. 


\section{HASIL DAN PEMBAHASAN}

Hasil analisis data meliputi tiga aspek, yakni: (1) struktur wacana dan hubungan keterpaduan antarunsur dalam wacana fiksimini; (2) permainan bahasa dalam wacana fiksimini bahasa Indonesia; dan (3) fungsi wacana fiksimini bahasa Indonesia. Berikut merupakan penjelasan mengenai ketiganya.

\section{Struktur dan Keterpaduan Antarunsur dalam Wacana Fiksimini}

Bahasan mengenai struktur dan keterpaduan antarunsur dalam wacana fiksimini bertumpu dari teori analisis struktur karya fiksi. Kenney (1966 dalam Pujiharto, 2010:23) menyatakan bahwa setelah melakukan pembacaan dengan cermat terhadap karya fiksi, seorang pembaca akan melanjutkannya dengan melakukan analisis terhadapnya. Analisis yang dimaksudkan ialah mengidentifikasi bagian-bagian yang membangun karya fiksi itu, menentukan hubungan di antara bagian-bagian itu, dan menemukan hubungan bagianbagian itu dengan keseluruhannya. Berikut merupakan pemaparan mengenai keduanya.

\section{Struktur Wacana Fiksimini}

Wacana fiksimini terdiri atas topik dan fiksimini. Selanjutnya, di dalam fiksimini terdapat dua bagian, yakni judul dan isi. Sebuah wacana fiksimini terdiri atas satu topik dan minimal satu fiksimini. Artinya, dalam wacana fiksimini, antara satu topik dengan topik lainnya memiliki jumlah fiksimini yang berbeda-beda. $\mathrm{Di}$ bawah ini merupakan percontohan pola struktur wacana fiksimini yang terdiri atas satu fiksimini (Gambar 2.1) maupun wacana fiksimini yang terdiri atas lebih dari satu fiksimini (Gambar 2.2).

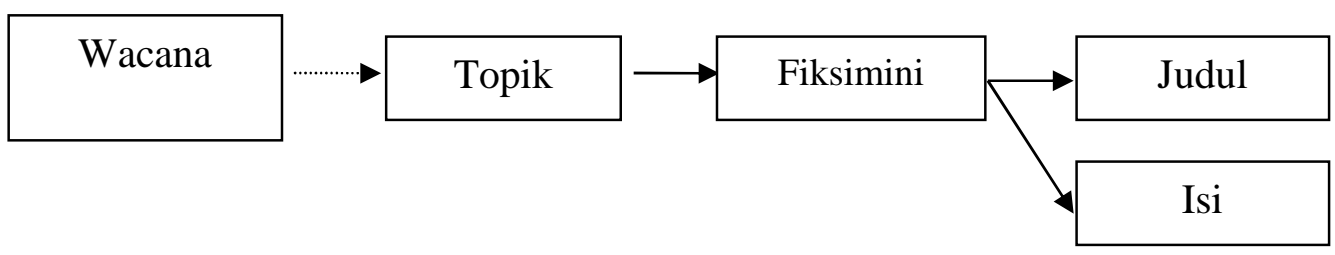

Gambar 2.1 Pola Struktur Wacana Fiksimini yang Terdiri Atas Satu Fiksimini

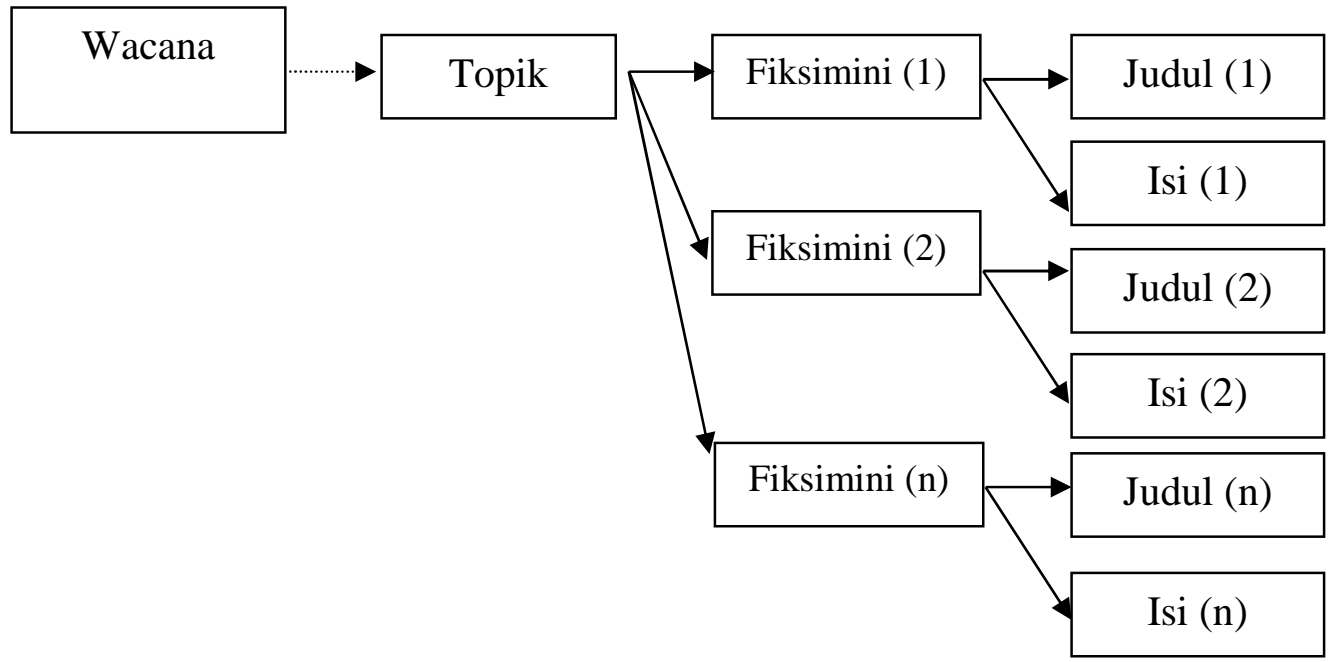

Gambar 2.2 Pola Struktur Wacana Fiksimini yang Terdiri Atas Lebih dari Satu Fiksimini 
Berdasarkan paparan di atas, struktur wacana fiksimini terdiri atas tiga unsur, yakni (1) topik, (2) judul, dan (3) isi. Data no (84) hingga (88) berikut merupakan percontohan mengenai ketiga unsur tersebut.

FITNAH adalah jalan sukses menuju kegagalan. Setuju? \#topikfiksimini (17 Juli 2014)

(84) MANTRA. "Aku difitnah, aku difitnah, aku difitnah..." diucapkannya berulangulang. Manjur juga, sekarang dia jadi presiden. (18 Juli 2014).

(85) KAMPANYE “Kenapa kamu jadi alim?” "Kan, fitnahnya begitu.” (18 Juli 2014).

(86) FITNAH LEBIH KEJAM DARI PEMBUNUHAN. "Tapi tak sesadis cinta ditolak!" Serunya sambil nunjuk dada. (18 Juli 2014).

(87) TERMAKAN FITNAH-Sebuah fakta tersesat di pikirannya. (18 Juli 2014).

(88) SAMPAI HARI TERAKHIR. Aku masih tak mau mendengar perkataannya. Tinggal aku yang hidup, yang lain termakan fitnah. (18 Juli 2014).

Dalam wacana fiksimini, topik ditulis menyerupai jumlah karakter fiksimini, tetapi tidak semua kalimat diberlakukan menjadi topik. Hanya bagian bercetak kapital yang disepakati menjadi topik fiksimini, yakni fitnah. Data pada no (84) hingga (88) merupakan fiksimini bertopik fitnah.

\section{Keterpaduan Antarunsur dalam Wacana Fiksimini}

Hubungan keterpaduan antar-ketiga unsurnya dapat dilihat melalui cara sederhanya, yakni penyebutan secara tersurat sebagian ataupun keseluruhan topik pada fiksimini. Oleh karenanya, terdapat tiga kemungkinan, yakni (1) penyebutan seluruh atau sebagian topik pada judul dan isi, (2) penyebutan seluruh atau sebagian topik pada judul fiksimini saja, dan (3) penyebutan seluruh atau sebagian topik pada isi fiksimini. Berikut merupakan penjelasan singkat dan percontohan dari ketiga kemungkinan tersebut.

Pertama, penyebutan seluruh atau sebagian topik pada judul dan isi. Keterpaduan fiksimini (44) dengan topik Tinta Di Jarimu telah nampak pada judul yang sama dengan topik. Selanjutnya, satuan lingual topik juga ditekankan kembali pada isi, yakni jari, di, dan tinta. Hal yang tak jauh berbeda juga ditunjukkan oleh fiksimini (66). Judul Penantian dikembangkan secara kreatif dari sebagian topiknya, yakni Menanti Sebuah Jawaban. Kemudian penggunaan sebagian topik juga ditemukan pada isi yang memuat jawaban sebagai bagian elemen pembentuk narasi pada isi.

Topik: Tinta di Jarimu

(44) TINTA DI JARI-“Sah! Sila celupkan jarimanisdi botol tinta yang sudah disiapkan,” ucap penghulu. (8 Juli 2014).

Topik: Menanti Sebuah Jawaban

(66) PENANTIAN-Tujuh tahun kusiapkan jawaban terbaikku, nyatanya ia tak pernah menanyakan cintaku. (14 Juli 2014).

Kedua, penyebutan seluruh atau sebagian topik pada judul fiksimini saja. 
Topik: Menanti Sebuah Jawaban

(67) MENANTI SEBUAH JAWABAN-Sekian lama. Ada yang menyentuh sujudku. (14 Juli 2014).

Topik: Mantan Terindah

(72) JADI MANTAN TERINDAH Sudah anak ketiga. Ita masih berharap begitu. (15 Juli 2014).

(73) MANTAN TERINDAH-Tubuhnya kuawetkan dalam lemari kaca. (15 Juli 2014).

Ketiga, penyebutan seluruh atau sebagian topik pada isi fiksimini.

Topik: Juara

(70) TURNAMEN SILAT “Lidah Ayahmu juara lagi, Nak.” (14 Juli 2014).

Topik: Fitnah

(84) MANTRA. "Aku difitnah, aku difitnah, aku difitnah..." diucapkannya berulang-ulang.

Manjur juga, sekarang dia jadi presiden. (18 Juli 2014).

(85) KAMPANYE “Kenapa kamu jadi alim?” “Kan, fitnahnya begitu.” (18 Juli 2014).

Ketiga kemungkinan tersebut merupakan bagian dari cara menampilkan keterpaduan wacana dengan menggunakan pengulangan atau repetisi. Rani, Arifin, dan Martutik (2004:130 - 132) turut menekankan bahwa pengulangan meupakan cara untuk menciptakan hubungan yang kohesif. Akan tetapi, harus dalam jumlah yang terbatas. Penggunaan yang berlebihan dapat menyebabkan gangguan keapikan bentuk wacana. Pengulangan berarti mempertahankan ide atau topik yang sedang dibicarakan. Dengan mengulang, berarti antara topik kalimat yang satu dengan kalimat sebelumnya yang diulang telah terkait.

Kandati demikian, keterpaduan tersurat pada wacana fiksimini menunjukkan perbedaannya dengan wacana naratif lainnya. Keterpaduan yang ditunjukkan dalam novel, cerpen, naskah drama, maupun teks naratif lainnya cenderung menggunakan piranti kohesi leksikal sebagai alat untuk menunjukkan adanya keterpaduan. Akan tetapi, fiksimini tidak menggunakan alat-alat semacam itu. Pembatasan jumlah karakter maksimal pada wacana fiksimini menyebabkan fiksimini lebih mengutamakan keterkaitan secara makna daripada bentuk. Berikut merupakan realisasi dari penjelasan tersebut.

Beberapa data menunjukkan adanya sejumlah fiksimini yang menggunakan judul berbeda dengan topik. Dalam kasus ini, keterpaduan wacana tidak dapat disimpulkan secara langsung sehingga turut menentukan kesukaran dalam keterbacaan wacananya. Hal tersebut sesuai dengan pendapat Alwi dkk (2003:438 -439) yang menyatakan bahwa hal yang menjadi masalah ialah bahwa tanpa topik sebagai judul, pembaca tidak segera memahami apa yang sedang dibicarakannya. Sebaliknya, dengan topik sebagai judul, pembaca dibimbing untuk memahami seluruh wacana sedikit demi sedikit.

Senada dengan hal tersebut, Van Dijk (1997 dalam Brown dan Yule, 1996:108) menyatakan bahwa topik-topik wacana rupanya mengurangi, menyusun, dan mengkategorikan informasi semantis rangkaian sebagai keseluruhan-keseluruhan. Oleh karenanya, terdapat enam relasi makna yang membentuk keterpaduan hubungan antara topik dengan judul fiksimini, yakni (1) antonimi, (2) hiponimi, (3) polisemi, dan (4) sinonimi, (5) kolokasi, dan (6) ekuivalensi. 


\section{Permainan Bahasa dalam Wacana Fiksimini}

Permainan bahasa dalam wacana fiksimini memiliki kedudukan yang sangat berharga. Perihal tersebut, Frente (2015) menyatakan bahwa permainan bahasa berperan penting dalam memberi bobot pada sebuah fiksimini. Hal itu meliputi efisiensi dan minimnya penggunaan kata yang sama. Penempatan susunan kalimat dalam penulisan sangat penting untuk menguatkan kesan 'ledakan' atau twist.

Kandati bukan tergolong wacana humor, fiksimini turut memiliki bagian yang dalam joke disebut punch. Mengenai bagaimana cara kerja joke, Papana (2012:84) menyatakan bahwa set up dari sebuah joke membangun apa yang dinamakan $1^{\text {st }}$ story. $1^{\text {st }}$ story menciptakan suatu harapan di dalam pikiran kita kemudian punch mengejutkan kita dengan apa yang disebut dengan $2^{\text {nd }}$ story yang walaupun sesuai dengan set up, tapi apa yang diungkapkan mengejutkan dan berbeda dengan apa yang kita pikirkan atau harapkan. Selanjutnya, Wijana (2003:305) turut menyempurnakan pendapat tersebut dengan berargumentasi bahwa untuk mempertahankan ketegangan, elemen yang mengandung kelucuan (punch line) sering kali tidak diungkapkan secara cepat, tetapi sengaja disimpan untuk diutarakan pada saat wacana mencapai klimaks.

Istilah punch dalam humor setara dengan twist dalam fiksimini. Twist atau ledakan dalam fiksimini mengandung penyimpangan bahasa yang memaksa pembaca turut mendefinisi ulangkan makna dari istilah-istilah yang dikisahkan. Frente (2015) mengatakan bahwa definisi sederhana dari twist itu cerita yang dipelintir dan atau diputar. Caranya dengan mengambil dari sudut pandang yang lain. Selain itu, disarankan untuk menciptakan kebaruan dari apa yang telah dipahami orang-orang. Fiksiminier sedari awal harus menggiring pembaca pada pemahaman yang umum dulu. Pada umumnya, twist terletak di akhir cerita. Dalam cerita tertentu, twis bersusun. Artinya, ada yang sudah sejak awal, lalu muncul lagi di akhir cerita.

Hal demikian sejalan dengan pendapat Aspahani (dalam Zaputra, 2015) yang mengemukakan bahwa fiksimini memiliki enam rukun iman, yakni: (1) plot dalam fiksimini terbuka bagai bom waktu yang menyimpan ledakan di awal dan di akhir cerita; (2) tokoh dalam fiksimini hadir samar tapi sangat kuat lewat ucap, pikir, atau laku yang mengejutkan; (3) dalam fiksimini, logika dibelok, ditabrak, dibanting, diremuk hingga tersembul hakikat yang lain; (4) makin mini, makin baik asal keminimannya itu bagai bikini yang menyimpan hal vital dan paling bikin penasaran; (5) puisi menyamarkan, fiksimini menegaskan. Pesannya tak memaksa tapi tak tertolak; dan (6) pada mulanya, fiksimini mengganggu pikiran, lalu mengajak merenung, dan akhirnya mencerahkan.

Keenam poin tersebut didukung oleh hadirnya twist yang sebagian besarnya dibentuk dari penyimpangan kaidah kebahasaan mulai aspek terkecil hingga terbesar. Aspek-aspek yang dibicarakan meliputi tiga permainan, yakni (1) fonologis, (2) morfologis, dan (3) makna. Penjelasan mengenai ketiga hal tersebut dipaparkan dalam tiga subbab berikut ini.

\section{Aspek Fonologis}

Satuan kebahasaan terkecil adalah bunyi. Ketika bunyi berpadu dan membentuk satuan kebahasaan yang lebih besar-kata, susunan bunyi tersebut memberikan peluang untuk menyerupai satu sama lain. Meski penyerupaan dapat dikenali melalui perbedaan makna yang melingkupi kata yang terbentuk, tetapi bentuk penyerupaan yang disengaja mampu menciptakan sensasi permainan bunyi tersendiri. 
Lebih jauh lagi, Wijana (2004:129-130) memberi penjelasan mengenai adanya permainan aspek fonologis yang dihubungkan dengan wacana kartun terjadi dengan mengacaukan harapan-harapan yang diasumsikan oleh peserta-peserta tindak tutur melalui penyimpangan bunyi. Beliau mencontohkan bahwa kata pagi dan bagi memiliki perbedaan makna karena peranan /p/ dan /b/ yang paradigmatik. Kemudian kata alir, liar, lari, dan lira masing-masing memiliki makna yang berbeda karena kedistingtifan bunyi-bunyi yang sintakmatik.

Kasus permainan bunyi karena sifat-sifat bunyi juga menjadi sarana bagi fiksiminier dalam usaha menciptakan twist pada fiksimininya. Permainan dari aspek fonologis meliputi dua, yakni pelesapan atau penghilangan bunyi dan subtitusi bunyi. Penjelasan mengenai salah satunya ialah sebagai berikut.

Data (637) berikut merupakan contoh fiksimini yang menunjukkan adanya bentuk permainan bunyi dengan menghilangkan salah satu hurufnya.

\section{CUMAN DI TANGGAL TUA. Hanya separuh bibirnya yang menempel di}

bibirku. (31 Oktober 2014).

Sekilas, fiksimini di atas tak nampak mengandung penghilangan bunyi. Akan tetapi, hal berbeda ditemukan apabila mencermati data tersebut lebih detail lagi. Isi fiksimini, yakni Hanya separuh bibirnya yang menempel di bibirku mengindikasikan adanya aktivitas yang coba disamarkan pada judul.

Pada data dikisahkan bahwa oleh sebab tanggal tua, maka bibir yang menempel menjadi tak sempurna, lebih tepatnya separuh saja. Penggunaan istilah cuman pada judul yang bersinonim dengan hanya pada pembukaan isi fiksimini mengarah pada kata ciuman. Terlebih lagi, aktivitas ciuman-lah yang melatarbelakangi kisahan peristiwa pada isi fiksimini.

Perubahan dari cuman yang seharusnya ciuman terjadi dengan menghilangkan bunyi /i/. Kesan vulgar akan nampak apabila fiksiminier tidak menghilangkan /i/ dengan tetap menggunakan CIUMAN DI TANGGAL TUA sebagai judul fiksimini itu. Dengan demikian fungsi penggantian bunyi tersebut dapat ditujukan untuk kepentingan menyamarkan istilah yang semula dianggap terlampau tabu. Senada dengan hal tersebut, Wijana dan Rohmadi (2012:59) menyatakan bahwa pada umumnya atau mulanya, eksploitasi bahasa digunakan untuk bersenda gurau, melucu atau mengejek, serta menertawakan sesuatu yang dianggap lucu atau ironis. Akan tetapi, tidak dipungkiri pula muncul modus yang lebih serius, namun nuansa jenakanya masih dapat ditangkap. Penggunaan bahasa seperti itu mungkin secara sengaja dikreasikan dan dapat pula secara tidak sengaja terbentuk atau ditemukan. Permainan bahasa yang disengajakan akan menimbulkan guyonan atau joke, sedangkan yang tidak disengajakan akan memunculkan humor.

\section{Aspek Morfologis}

Kata dibentuk melalui serangkaian proses yang beberapa di antaranya telah diteorikan mulai dari afiksasi, reduplikasi, komposisi, dan abreviasi. Oleh karenanya, ada semacam 'aturan' dalam pembentukkan kata. Meski demikian, tidak semua proses dijalankan sesuai dengan aturan penyusunannya. Dalam kasus wacana fiksimini, beberapa aspek morfologis sengaja diabaikan untuk mencapai kepentingan tertentu. Sejauh yang diamati, terdapat tiga aspek morfologi yang disimpangkan, yakni (1) permainan ambiguitas imbuhan, (2) 
permainan kata majemuk, dan (3) permainan akronim. Berikut merupakan pemaparan perihal satu dari ketiga butir tersebut.

Ambiguitas imbuhan menjadi salah satu sarana kebahasaan yang dapat dijadikan bahan permainan. Fiksimini (438) berjudul INFLASI, (498) berjudul KESEMUTAN, dan (104) berjudul PILIHAN di bawah ini menguatkan argumentasi tersebut.

\section{INFLASI. Harga sayur-sayuran naik. "Apalagi sayur beneran," keluhnya ibu-} ibu (10 September 2014).

Sayur-sayuran pada data di atas mengalami ambiguitas yang dibangun dari penyimpangan imbuhan. Awalnya, tidak ada yang salah dengan kata sayur-sayuran. Akan tetapi, setelah adanya penyertaan sayur beneran pada dialog selepas kalimat pertama dalam isi fiksimini di atas, baru diketahui bahwa pemaknaan akhiran -an pada kata tersebut diplesetkan. Sebelum dibubuhi akhiran -an, kata sayur telah mengalami proses reduplikasi utuh terlebih dahulu. Untuk itulah, Kridalaksana (2007:96-97) menuliskan tiga makna reduplikasi $(\mathrm{R})$ pembentuk nomina yang mengombinasikan (R) dengan konfiks -an, yakni: (1) 'bermacam-macam', contohnya Kamu harus banyak makan sayur-sayuran supaya sehat; (2) 'yang mirip', contohnya waktu saya masih kecil, saya sering membuat rumahrumahan; (3) 'melakukan sesuatu mirip dengan sifat', contohnya anak-anak itu sedang bermain kucing-kucingan di halaman sekolah.

Kamus Besar Bahasa Indonesia (Pusat Bahasa, 2010) mendefinisikan inflasi menurut istilah ekonomi yang artinya kemerosotan nilai uang (kertas) karena banyaknya dan cepatnya uang (kertas) beredar sehingga menyebabkan naiknya harga barang-barang. Dengan dihubungkan dengan arti judulnya, sayur-sayuran yang sejatinya bermakna 'bermacam-macam jenis sayur' diplesetkan menjadi ‘sesuatu yang mirip sayur atau sayuran palsu'.

\section{Aspek Makna}

Aspek makna dalam wacana fiksimini meliputi sebelas permainan: (1) idiom, (2) citraan, (3) permainan bentuk-bentuk berhomonim, (4) antonimi, (5) polisemi, (6) sinonimi, (7) analogi, (8) metafora, (9) meronimi, (10) metonimi, dan (11) subtitusi. Satu dari kesebelas pemainan makna tersebut dipaparkan sebegai berikut.

Keraf (1985:109) menyatakan bahwa idiom adalah pola-pola struktural yang menyimpang dari kaidah-kaidah bahasa yang umum, biasanya berbentuk frasa, sedangkan artinya tidak bisa diterangkan secara logis atau secara gramatikal dengan bertumpu pada makna kata-kata yang membentuknya. Data (95) berikut merupakan percontohan dari ilustrasi tersebut.

(95) NAKSIR. Aku dan dia, saling pandang dengan sebelah mata (22 Juli 2014).

Sebelah mata lazimnya diartikan sebagai seseorang yang dianggap sepele, remeh, tidak penting, ataupun tak berharga. Akan tetapi, arti tersebut tidak sesuai dengan judul fiksimininya, yakni naksir. Oleh karenanya, sebelah mata harus didefiniulangkan dan dihubungkan dengan aktivitas yang merupakan indikator ketika seseorang menyukainaksir —orang lain.

Jadi, sebelah mata yang semua merupakan idiom diubah ke aktivitas memandang seseorang dengan mata sebelah-melemparkan tatap dengan mengernyitkan sebelah mata. Lazimnya, tatapan tersebut dalam budaya Timur dipandang sebagai tatapan 'nakal dan atau 
menggoda'. Akibat penyimpangan ini pula, makna idiom yang semula menjadi berbeda sama sekali.

\section{Fungsi Wacana Fiksimini}

Fiksimini merupakan wacana yang dikembangkan berdasarkan spesifikasi media sosial twitter yang bermakna kicauan. Oleh karenanya, satu judul fiksimini disetarakan sebagai satu kicauan yang ditulis fiksiminier. Untuk itulah, kicauan dalam bentuk fiksimini tidak hanya dipandang sebagai wacana narasi semata, melainkan juga sebagai karya yang menjalankan fungsinya. Dalam realisasinya, wacana fiksimini mengandung empat fungsi. Keempat fungsi tersebut, yakni (1) fungsi emotif yang memandang fiksimini sebagai sarana untuk mengekspresikan perasaan atau emosi, (2) fungsi retorikal sebagai alat untuk menyindir dan menyampaikan kritik terhadap kondisi sekitar, (3) fungsi kognitif sebagai bagian untuk menarasikan atau menceritaan peristiwa berkenaan dengan topik tertentu, dan (4) fungsi poetic speech yang melihat fiksimini sebagai alat untuk mengekspresikan imajinasi dan untuk hiburan, berhumor, serta bercanda. Berikut merupakan penjelasan satu dari keempat fungsi wacana fiksimini.

Dilihat dari sudut penutur, maka bahasa itu berfungsi personal atau pribadi yang oleh Jakobson disebut fungsi emotif. Maksudnya, penutur mempunyai sikap terhadap apa yang dituturkannya. Si penutur bukan hanya mengungkapkan emosi lewat bahasa, tetapi juga memperlihatkan emosi itu sewaktu menyampaikan tuturannya. Dalam hal ini, pihak si pendengar juga dapat menduga apakah si penutur sedih, marah atau gembira.

(12) PINTAR MERAYU dia membolak-balik perasaankku. Kini saat sedih, aku malah tertawa (4 Juni 2014).

(63) PERASAAN. Kami saling mengerti jawaban masing-masing, hanya menanti siapa lebih dulu bertanya (12 Juli 2014).

Fiksimini (12) berjudul PINTAR MERAYU merupakan ungkapan perasaan terhadap sosok "dirinya" yang pandai dalam membolak-balikan perasaan sehingga tangisan yang selayaknya mewakili perasaan sedih, berganti jadi ekspresi tertawa. Selanjutnya, perasaan cinta yang sama-sama dirasakan oleh kedua orang ternyata belum juga dapat menyatukan mereka karena gengsi dilukiskan pada fiksimini (63) berjudul PERASAAN. Fungsi tersebut sejalan dengan saran yang disampaikan Baskoro (2014) bahwa hendaknya sebuah tulisan diarahkan untuk mengekspresikan empatinya terhadap orang lain.

\section{PENUTUP}

Ciri paling menonjol dari wacana fiksimini ialah bentuk dan media berkembangnya. Keduanya saling mendukung untuk menciptakan sebentuk wacana 140 karakter. Oleh karena hanya mematok jumlah karakter maksimal, para fiksiminier diizinkan mengkreasikan sedemikian rupa sehingga tak ada aturan pasti perihal struktur. Setali dua uang, untuk meminikan karakter, fiksiminier dituntut cakap dalam memainkan bahasa. Itulah salah satu fungsi permainan bahasa dalam wacana fiksimini yang pada umumnya disajikan dengan menghadirkan pemahaman umum pembacanya, kemudian disimpangkan menggunakan beberapa varian aspek kebahasaan. Tak berhenti sampai di sana, wacana yang dibangun dari beberapa fiksiminier turut menhadirkan keberagaman fungsi bahasa pula sehingga menuntut konsentrasi pembacanya untuk menerka. 
Lebih dari itu semua, hadirnya fiksimini mampu membuktikan bahwa bahasa mudah dalam mengadaptasikan diri dengan kecenderungan media yang tengah berkembang. Selanjutnya, patut diakui bahwa penelitian ini belum secara spesifik meneliti tentang twist atau ledakan yang terdapat dalam fiksimini. Selain itu, dunia maya yang mengalami perkembangan dalam satuan detik memungkinkan timbulnya revolusi tren atau kecenderungan-kecenderungan baru sehingga penelitian berkesinambungan mengenai wacana fiksimini diperlukan.

\section{DAFTAR RUJUKAN}

Alwi, H., Dardjowidjojo, S., Lapoliwa, H. \& Moeliono, A. M.. 2003. Tata Bahasa Baku Bahasa Indonesia Edisi Ketiga. Jakarta: Balai Pustaka.

Baskoro, B.R.S. 2014. Pragmatik dan Wacana Korupsi. Humaniora. Volume 26 (1) Februari 2014. Universitas Gadjah Mada Yogyakarta.

Brown \& Yule. 1996. Analisis Wacana (Discourse Analysis). Terjemahan Soetikno. Jakarta: Gramedia Pustaka Utama.

Budiwati, T.N. 2011. Representasi Wacana Gender dalam Ungkapan Berbahasa Indonesia dan bahasa Inggris: Analisis Wacana Kritis. Kawistara. Volume 1 (3) Desember 2011: Yogyakarta.

Faruk. 2011. Sastra dalam Masyarakat (Ter-)multimediakan(-kan): Implikasi Teoretik, Metodologis, dan Edukasionalnya. Pidato Pengukuhan jabatan Guru Besar pada Fakultas Ilmu Budaya UGM. Yogyakarta: Universitas Gadjah Mada.

Kartikasari, R; N. Anoegrajekti, dan Muslikatin, T. 2014. Realitas Sosial Dan Representasi Fiksimini dalam Tinjauan Sosiologi Sastra. Publika Budaya. Volume 2 (1) Maret 2014: Jember.

Keraf, G. 1985. Diksi dan Gaya Bahasa. Jakarta: Gramedia.

Kridalaksana, H. 2007. Pembentukan Kata dalam Bahasa Indonesia. Jakarta: Gramedia.

Oka, I. G. N \& Suparno. 1994. Linguistik Umum. Jakarta: Direktorat Jenderal Pendidikan Tinggi Departemen Pendidikan dan kebudayaan.

Papana, R. 2012. Kiat Tahap Awal Belajar Stand Up Comedy Indonesia Kitab Suci. Jakarta: Mediakita.

Pujiharto. 2010. Pengantar Teori Fiksi. Yogyakarta: Penerbit Elmatera.

Pusat Bahasa. 2013. Kamus Besar Bahasa Indonesia Edisi Keempat. Jakarta: Kerjasama Departemen Pendidikan Nasional dan Penerbit Gramedia.

Rani, A., Arifin, B., \& Martutik. 2004. Analisis Wacana: Sebuah kajian Bahasa dalam Pemakaian. Malang: Bayumedia Publishing.

Sudaryanto. 1993. Metode dan Aneka Teknik Analisis Bahasa. Yogyakarta: Duta Wacana University Press.

Wijana, I. D. P., \& M. Rohmadi. 2011. Analisis Wacana Pragmatik Kajian Teori dan Analisis. Surakarta: Yuma Pustaka.

Wijana, I. D. P., dan M. Rohmadi. 2012. Sosiolinguistik Kajian Teori dan Analisis. Yogyakarta: Pustaka Pelajar.

Wijana, I. D.P. 2003. Wacana Dagadu, Permainan Bahasa, dan Ilmu Bahasa. Pidato Pengukuhan jabatan Guru Besar pada Fakultas Ilmu Budaya UGM. Yogyakarta: Universitas Gadjah Mada.

Wijana, I. D. P. 2004. Kartun. Yogyakarta: Ombak. 
Frente, O. 2015. Wawancara online via email pada 16 Februari 2015 dengan Ketua Nasional Komunitas Fiksimini: koordinator online maupun offline.

Zaputra, E. 2015. Wawancara online pada 16 Februari 2015 dengan fiksiminier @Enrouz Zaputra. 